\title{
LEGALITAS PEMERIKSAAN SIDANG PERKARA PIDANA MELALUI MEDIA TELECONFERENCE DI MASA PANDEMI COVID-19
}

\author{
Faisal Cahyadi \\ Fakultas Hukum, Universitas Gadjah Mada \\ e-mail: faisal.cahyadi@mail.ugm.ac.id \\ Hilda Restu Utami \\ Fakultas Hukum, Universitas Gadjah Mada \\ e-mail: hildarestu99@mail.ugm.ac.id
}

disampaikan 14/09/2020 - di-review 02/11/2020 - diterima 20/11/2021

DOI: $10.25123 /$ vej.v7i2.4243

\begin{abstract}
The purpose of this research is to identify the legal basis for implementation of virtual criminal court as response to the COVID-19 pandemic and emerging legal issues. By tracing existing legal sources, browsing throuhg relevant legal literature and interviewing legal practioners, the author draws two general observations. The first is that what is used as the legal basis justifung virtual criminal court proceding are circular letter and a private contractual arrangement. Both should not be considered legally valid to exempt the prevailing law on general procedural rules. In addition, the actual practice of virtual criminal court examination violates the principle of having the physical presence of the accused before court. The accused follows the whole process in the place where he/she is detained.
\end{abstract}

Keywords:

criminal court proceeding; virtual court; COVID-19 pandemic;

\begin{abstract}
Abstrak
Tujuan penelitian ini adalah mengidentifikasi sumber-sumber hukum positif yang mengatur pelaksanaan sidang virtual perkara pidana di Indonesia di masa pandemi COVID-19 dan masalah hukum yang muncul darinya. Dengan menelusuri sumber hukum, pustaka dan sejumlah wawancara pada sejumlah praktisi hukum, dapat diajukan dua simpulan umum. Pertama adalah bahwa dasar hukum pelaksanaan sidang virtual adalah surat edaran dan perjanjian kerjasama yang tidak dapat mengeyampingkan aturan-aturan beracara dalam KUHAP. Selanjutnya bahwa pelaksanaan sidang virtual ternyata melanggar ketentuan wajib hadirnya terdakwa di ruang sidang sebagaimana diwajibkan KUHAP. Terdakwa selama persidangan berlangsung tetap berada di Rutan/Lapas.
\end{abstract}

Kata Kunci: persidangan pidana; sidang virtual; pandemi COVID-19;

\section{Pendahuluan}

Pada tanggal 11 Maret 2020, World Health Organization (WHO)
menetapkan Coronavirus Disease 2019 (COVID-19) sebagai pandemi ${ }^{1}{ }^{2}$ Saat

1 Pandemi adalah istilah dalam dunia kesehatan mengenai penyebaran penyakit yang terjadi di seluruh dunia atau wilayah yang sangat luas melintasi batas internasional dan menjangkit banyak orang. Lihat dalam World Health Organization, The Classical Definition of A Pandemic is 
ditetapkan, sudah ada 118.000 kasus terkonfirmasi COVID-19 di dunia yang tersebar pada 114 negara di mana 4.291 diantaranya telah dinyatakan meninggal dunia. ${ }^{3}$ Menurut WHO, angka tersebut telah meningkat tiga belas kali lipat dan negara yang terdampak juga meningkat hingga tiga kali lipat. ${ }^{4}$ Bahkan sampai dengan 9 Juli 2020, angka tersebut terus bertambah hingga terdapat 11.874.226 kasus terkonfirmasi COVID-19 di dunia, termasuk di dalamnya 545.481 orang meninggal dunia. ${ }^{5}$ Penyebaran COVID-19 terjadi secara eksponensial dan masif lintas negara bahkan lintas benua. Penyebabnya karena virus tersebut dapat dengan mudah menyebar dari kontak dekat antar-manusia melalui percikan air liur (droplets).6 Ditambah lagi, setidaknya sampai dengan Juli 2020, para ahli di bidang kesehatan belum menemukan obat antivirus atau vaksin yang telah diuji secara klinis dapat mengatasi COVID-19.7

Di Indonesia sendiri, kasus COVID-19 pertama kali diumumkan langsung oleh Presiden Joko Widodo pada tanggal 2 Maret 2020 dengan menyatakan bahwa terdapat dua orang warga negara Indonesia positif terinfeksi COVID-19.8 Dalam perkembangannya, angka tersebut semakin bertambah dalam setiap harinya. Akibatnya, COVID-19 juga berdampak pada aspek ekonomi, sosial, hingga kesejahteraan masyarakat di Indonesia. Berdasarkan hal tersebut, pada tanggal 31 Maret 2020, Presiden menetapkan COVID-19 sebagai penyakit yang menimbulkan kedaruratan kesehatan masyarakat berdasarkan Keputusan Presiden Republik

Not Elusive, https://www.who.int/bulletin/volumes/89/7/11-

088815/en/\#: :text=A\%20pandemic\%20is\%20defined\%20as,are\%20not $\% 20$ considered $\% 2$ Opandemics., diakses 9 Juli, 2020.

2 World Health Organization, WHO Director-General's Opening Remarks at The Media Briefing on COVID-19-11 March 2020", https://www.who.int/dg/speeches/detail/who-director-general-sopening-remarks-at-the-media-briefing-on-covid-19---11-march-2020, diakses 9 Juli, 2020.

3 Id.

4 Id.

5 World Health Organization, "WHO Coronavirus Diesease (COVID-19) Dashboard", https://covid19.who.int/, diakses 10 Juli 2020

6 Harapan Harapan, et.al., Coronavirus Disease 2019 (COVID-19): A Literature Review, 13 Journal of Infection and Public Health, 667, 668, May 2020.

7 Muhammad Adnan Shereen, et.al., COVID-19 Infection: Origin, Transmission, and Characteristics of Human Coronaviruses, 24 Journal of Advanced Research, 91, 91, July 2020.

8 Kompas, Breaking News: Jokowi Umumkan Dua Orang di Indonesia Positif Corona, https://nasional.kompas.com/read/2020/03/02/11265921/breaking-news-jokowiumumkan-dua-orang-di-indonesia-positif-corona?page=all, diakses $10 \mathrm{Juli}, 2020$. 
Indonesia Nomor 11 Tahun 2020 tentang Penetapan Kedaruratan Kesehatan Masyarakat Corona Virus Disease 2019 (COVID-19). Bersamaan dengan keputusan tersebut, pemerintah juga memutuskan untuk menerapkan Pembatasan Sosial Berskala Besar (PSBB).

Selain menerapkan PSBB, pemerintah juga mengeluarkan kebijakan physical distancing dalam setiap kegiatan. Hal ini menyebabkan beberapa instansi harus menyesuaikan sistem kerja yang semula Work From Office dengan bertatap muka secara langsung menjadi Work From Home secara virtual (online). Akibatnya, institusi pengadilan pun juga harus menyesuaikan sistem kerja di lingkungan pengadilan termasuk dalam pelaksanaan persidangan. Sebagai upaya guna menyesuaikan perubahan sistem kerja tersebut, Ketua Mahkamah Agung Republik Indonesia (Ketua MA) menerbitkan Surat Edaran Mahkamah Agung Republik Indonesia Nomor 1 Tahun 2020 tentang Pedoman Pelaksanaan Tugas Selama Masa Pencegahan Penyebaran Corona virus Disease 2019 (COVID-19) di Lingkungan Mahkamah Agung dan Badan Peradilan yang Berada di Bawahnya (SEMA No. 1 Tahun 2020).

Salah satu isi dari SEMA No. 1 Tahun 2020 yaitu khusus untuk perkara pidana, pidana militer, dan jinayah yang terdakwanya sedang ditahan dan penahanannya tidak dapat diperpanjang lagi selama masa pencegahan penyebaran COVID-19, maka persidangannya tetap dapat dilaksanakan. ${ }^{9}$ Namun, dalam hal penahanan terdakwa masih dapat diperpanjang, maka persidangannya ditunda sampai dengan berakhirnya masa pencegahan penyebaran COVID-19.10 Permasalahan pun timbul dengan ditundanya pelaksanaan persidangan sebab hal tersebut menimbulkan ketidakpastian hukum bagi terdakwa yang memiliki hak untuk segera diadili oleh pengadilan guna menjauhkan kemungkinan terkatungkatungnya nasib terdakwa, terutama bagi terdakwa yang dilakukan penahanan. ${ }^{11}$

9 Surat Edaran Mahkamah Agung R.I., No. 1 tahun 2020, Pedoman Pelaksanaan Tugas Selama Masa Pencegahan Penyebaran Coronavirus Disease 2019 (COVID-19) di Lingkungan Mahkamah Agung dan Badan Peradilan yang Berada di Bawahnya, butir 2 huruf a.

10 Id., butir 2 huruf $b$.

11 Undang-Undang R.I., No. 8 Tahun 1981, Hukum Acara Pidana, L.N.R.I. Tahun 1981, No. 76, Pasal 50 ayat (3) dan Penjelesannya. 
Demi menjawab permasalahan hukum di atas, Menteri Hukum dan Hak Asasi Manusia Republik Indonesia (Menkumham), Jaksa Agung Republik Indonesia (Jaksa Agung), dan Direktur Jenderal Badan Peradilan Umum Mahkamah Agung Republik Indonesia (Dirjen Badilum) mengeluarkan surat edaran yang pada pokoknya mengatur bahwa persidangan perkara pidana dapat dilaksanakan melalui teleconference selama masa pandemi COVID-19. ${ }^{12}$ Lebih lanjut lagi, pada tanggal 13 April 2020, Mahkamah Agung Republik Indonesia (MARI), Kejaksaan Agung Republik Indonesia (Kejagung), dan Kementerian Hukum dan Hak Asasi Manusia Republik Indonesia (Kemenkumham) menyepakati Perjanjian Kerja Sama Nomor 402/DJU/HM.01.1/4/2020, Nomor KEP17/E/Ejp/04/2020, Nomor PAS-08.HH.05.05 Tahun 2020 tentang Pelaksanaan Persidangan Melalui Teleconference (Perjanjian Kerja Sama MA, Kejagung, dan Kemenkumham tentang Pelaksanaan Persidangan Melalui Teleconference). Perjanjian tersebut sebagai pedoman para pihak untuk melaksanakan persidangan melalui teleconference. ${ }^{13}$ Dalam perjanjian ini juga diatur mengenai pembagian wewenang dan tanggung jawab para pihak, seperti menyediakan sarana dan prasarana penunjang yang memadai guna kepentingan persidangan melalui teleconference di tempat masing-masing. ${ }^{14}$ Selain itu, Kemenkumham juga berwenang dan bertanggung jawab untuk mempersiapkan tahanan dan/atau warga binaan pemasyarakatan yang berstatus sebagai terdakwa/saksi dalam persidangan melalui teleconference di rumah tahanan (Rutan)/Lembaga pemasyarakatan (Lapas) setempat. ${ }^{15}$

12 Surat Menteri Hukum dan Hak Asasi Manusia R.I., No. M.HH.PK.01.01.01-03, Pencegahan dan Pengendalian Penyebaran Coronavirus Disease 2019 (COVID-19) di Lapas/Rutan. Lihat juga dalam Surat Jaksa Agung R.I., No. B-049/A/SUJA/03/2020 Tahun 2020, Optimalisasi Pelaksanaan Tugas, Fungsi, dan Kewenangan di Tengah Upaya Mencegah Penyebaran COVID19, butir 2 dan Surat Direktur Jenderal Badan Peradilan Umum Mahkamah Agung R.I., 379/DJU/PS.00/3/2020, Persidangan Perkara Pidana Secara Teleconference.

13 Perjanjian Kerja Sama antara Mahkamah Agung Republik Indonesia, Kejaksaan Republik Indonesia, dan Kementerian Hukum dan Hak Asasi Manusia Republik Indonesia, No. 402/DJU/HM.01.1/4/2020, No. KEP-17/E/Ejp/04/2020, No. PAS-08.HH.05.05 Tahun 2020, Pelaksanaan Persidangan Melalui Teleconference, Pasal 1 ayat (1).

14 Id., Pasal 3 ayat (1) butir b jo. Pasal 3 ayat (2) butir b jo. Pasal 3 ayat (3) butir c.

15 Id., Pasal 3 ayat (3) butir b. 
Berkaitan dengan pelaksanaan sidang perkara pidana secara teleconference di masa pandemi COVID-19 dengan cara terdakwa tetap berada di dalam Rutan atau Lapas, bahwa pelaksanaan sidang dengan cara tersebut dianggap bertentangan dengan Pasal 154 ayat (1) Kitab Undang-Undang Hukum Acara Pidana (KUHAP). Adapun, ketentuan tersebut pada pokoknya mengatur bahwa hakim ketua sidang memerintahkan agar terdakwa dipanggil masuk untuk dihadapkan/dihadirkan ke persidangan dalam keadaan bebas. ${ }^{16}$ Dari ketentuan di atas, dapat dipahami bahwa rasio dari pasal ini adalah terdakwa hadir secara fisik dan langsung di ruang sidang pengadilan dalam keadaan bebas, baik jasmani maupun rohaninya. Selain itu, Perjanjian Kerja Sama MA, Kejagung, dan Kemenkumham tentang Pelaksanaan Persidangan Melalui Teleconference merupakan bagian dari ranah hukum perdata yang sifatnya mengikat para pihak yang membuatnya. Dalam hal ini, para pihak yang membuat perjanjian tersebut adalah MA, Kejagung, dan Kemenkumham. Namun, perlu diketahui bahwa dalam hukum acara pidana, pihak-pihak yang beracara tidak hanya sebatas para pihak di atas, melainkan juga terdapat pihak ketiga seperti terdakwa dan penasihat hukum. Hal ini tentu menimbulkan sebuah polemik tersendiri yang layak untuk dikaji, apakah perjanjian kerja sama tersebut dapat dijadikan sebagai payung hukum untuk beracara dalam peradilan pidana?

Berdasarkan latar belakang masalah di atas, Penulis memandang perlu untuk dilakukan penelitian. Adapun, penelitian ini bertujuan guna menjawab dua rumusan masalah. Pertama, pengaturan pemeriksaan sidang perkara pidana melalui media teleconference di Indonesia. Kedua, legalitas pemeriksaan terdakwa di persidangan melalui media teleconference di Indonesia selama masa pandemi COVID-19.

Penelitian ini adalah penelitian hukum normatif. Penelitian hukum normatif di sini dilakukan dengan cara mengidentifikasi peraturan perundangundangan yang mengatur mengenai pemeriksaan sidang perkara pidana melalui media teleconference di Indonesia dan menganalisis legalitas pemeriksaan

16 Undang-Undang R.I., No. 8 Tahun 1981, Hukum Acara Pidana, L.N.R.I. Tahun 1981 No. 76, Pasal 154 ayat (1). 
terdakwa di persidangan melalui media teleconference di Indonesia selama masa pandemi COVID-19.

Bahan hukum diperoleh Penulis melalui studi kepustakaan mengenai pemeriksaan sidang perkara pidana melalui media teleconference dan legalitas pemeriksaan terdakwa di persidangan melalui media teleconference di Indonesia selama masa pandemi COVID-19 serta melakukan wawancara baik dengan jaksa maupun advokat. Data yang telah diperoleh dari hasil penelitian tersebut kemudian dianalisis secara kualitatif.

\section{Pembahasan}

\section{Pengaturan Pemeriksaan Sidang Perkara Pidana Melalui Media Teleconference di Indonesia}

Perkembangan teknologi informasi dan komunikasi yang sangat pesat, telah membawa dunia pada era digitalisasi. Dengan mengadopsi teknologi, masyarakat pun terus berkembang secara dinamis. Sebagai implikasi dari kehadiran teknologi tersebut, kini setiap orang dapat dengan mudah saling berkomunikasi tanpa terbatas jarak dan waktu. Salah satu teknologi yang memberikan kemudahan tersebut adalah teleconference.

Menurut kamus istilah teknologi informasi, teleconference diartikan sebagai pertemuan dua orang ataupun lebih dengan menggunakan telepon atau koneksi jaringan. ${ }^{17}$ Pertemuan tersebut memungkinkan peserta untuk berinteraksi melalui suara (audio conference) saja atau bahkan dengan menggunakan video (video conference) agar peserta dapat saling melihat satu sama lain. ${ }^{18}$ Berdasarkan pengertian di atas, teleconference dapat dibagi menjadi dua macam, yaitu: ${ }^{19}$

\footnotetext{
Fathul Wahid, Kamus Istilah Teknologi Informasi, Andi Offset, Yogyakarta, 2002, hlm. 347. Id.

19 Sintha Dewi, 2012, Kajian Yuridis Terhadap Keterangan Saksi Melalui Audio Visual (Teleconference) di Persidangan Perkara Pidana, Tesis, Program Pascasarjana Hukum dan Sistem Peradilan Pidana Fakultas Hukum Universitas Indonesia, Jakarta, hlm. 93.
} 
1. Audio conference, di mana peserta dapat saling berbicara satu sama lain seperti dalam telepon. Namun, audio conference melibatkan lebih dari dua orang, sementara telepon tidak.

2. Video conference, di mana peserta dapat saling saling melihat satu sama lain melalui layar yang tersedia.

Dalam perkembangannya, media teleconference mulai digunakan dalam berbagai aspek kehidupan, termasuk bidang hukum, salah satunya adalah digunakannya teleconference dalam persidangan pidana. Sejarah mencatat bahwa persidangan pidana dengan memanfaatkan teleconference pertama kali di Indonesia dilakukan dalam kasus tindak pidana korupsi atas nama terdakwa Rahardi Ramelan yang didakwa terkait dengan kasus penyalahgunaan dana nonbudgeter badan urusan logistik pada tahun 2002.20 Saat persidangan, saksi B.J. Habibie tidak dapat memberikan keterangannya di Pengadilan Negeri Jakarta Selatan karena sedang menemani isterinya yang sedang sakit di Hamburg, Jerman. ${ }^{21}$ Akan tetapi, majelis hakim dalam perkara a quo berpendapat bahwa saksi B.J. Habibie merupakan saksi sentral sehingga diperlukan keterangannya untuk didengar mengingat bergulirnya dana badan urusan logistik berawal dari kebijakan saksi yang saat itu sedang menjabat sebagai Presiden Republik Indonesia. ${ }^{22}$ Lebih lanjut lagi, majelis hakim berpendapat bahwa pemeriksaan saksi tersebut ditujukan guna memperoleh kebenaran materiel dari perkara $a$ quo. ${ }^{23}$ Selain kasus di atas, persidangan pidana dengan memanfaatkan media teleconference juga sudah beberapa kali dilakukan di Indonesia antara lain dalam kasus pelanggaran berat HAM atas nama terdakwa Hulman Gultom ${ }^{24}$, tindak

20 Ruth Marina Damayanti Siregar, Legalitas Keterangan Saksi Melalui Teleconference sebagai Alat Bukti dalam Perkara Pidana, 5 Jurisprudence, 25, 26, Maret 2015.

21 Sekar Dianing Pertiwi Soetanto, 2008, Perkembangan Alat Bukti dalam Pembuktian Tindak Pidana pada KUHAP dan Undang-Undang Khusus di Indonesia, Skripsi, Program Studi Ilmu Hukum Fakultas Hukum Universitas Sebelas Maret, Surakarta, hlm. 16-17.

22 Lalu Mariyun, 2004, Penyelenggaraan Sidang Pengadilan dengan Metode Teleconference Ditinjau dari Aspek Hukum Pembuktian (Studi Kasus Perkara Pidana No. 354/PID/B/2002/PN.JAK-SEL.), Tesis, Program Pascasarjana Fakultas Hukum Universitas Gadjah Mada, Yogyakarta, hlm. 16.

23 Id.

24 Sintha Dewi, supra no. 19, hlm. 126. 
pidana terorisme atas nama terdakwa Abu Bakar Ba'asyir ${ }^{25}$ dan Ali Gufron ${ }^{26}$, hingga kasus penembakan di Lapas Cebongan, Yogyakarta ${ }^{27}$.

Berkaitan dengan pengaturan pemeriksaan sidang perkara pidana melalui media teleconference di Indonesia, terdapat beberapa ketentuan yang mengatur mengenai dapat dilaksanakannya persidangan pidana melalui sarana elektronik, yaitu:

1. Undang-Undang Republik Indonesia Nomor 13 Tahun 2006 tentang Perlindungan Saksi dan Korban sebagaimana telah diubah dan ditambah dengan Undang-Undang Republik Indonesia Nomor 31 Tahun 2014 tentang Perubahan atas Undang-Undang Republik Indonesia Nomor 13 Tahun 2006 tentang Perlindungan Saksi dan Korban (UU Perlindungan Saksi dan Korban)

Pasal 9 ayat (3) UU No.13 Tahun 2006 pada pokoknya mengatur bahwa saksi dan/atau korban dapat didengar keterangannya secara langsung melalui sarana elektronik dengan didampingi oleh pejabat yang berwenang. ${ }^{28}$ Pendampingan oleh pejabat yang berwenang ini dimaksudkan untuk memastikan bahwa saksi dan/atau korban tidak dalam paksaan atau tekanan ketika memberikan keterangan. ${ }^{29}$ Adapun, syarat untuk dapat dilaksanakannya pemeriksaan secara teleconference yaitu saksi dan/atau korban harus berada dalam ancaman yang sangat besar. ${ }^{30}$ Sementara itu, ancaman di sini maksudnya adalah segala bentuk perbuatan yang menimbulkan akibat, baik langsung maupun tidak langsung sehingga saksi dan/atau korban merasa takut atau dipaksa untuk melakukan atau tidak

25 Lalu Mariyun, supra no. 22, hlm. 68-69.

26 Lulu Azmi Sharfina, 2018, Keabsahan Kesaksian (Keterangan Saksi) yang Disampaikan Secara Teleconference di Persidangan, Skripsi, Program Studi Ilmu Hukum Fakultas Hukum Universitas Islam Indonesia, Yogyakarta, hlm. 84.

27 Dien Kalpika Kasih, 2014, Keterangan Saksi Video Conference pada Kasus Cebongan Yogyakarta (Tinjauan Yuridis Putusan No. 48-K/PM II-11/AD/VI/2013), Skripsi, Program Studi Ilmu Hukum Fakultas Hukum Universitas Jenderal Soedirman, Purwokerto, hlm. 2-3.

28 Undang-Undang R.I., No. 13 Tahun 2006, Perlindungan Saksi dan Korban, L.N.R.I. Tahun 2006 No. 64, Pasal 9 ayat (3).

29 Id., Penjelasan Pasal 9 ayat (3).

30 Id., Pasal 9 ayat (1). 
melakukan sesuatu hal yang berkenaan dengan pemberian kesaksiannya dalam suatu proses peradilan pidana. ${ }^{31}$

2. Undang-Undang Republik Indonesia Nomor 11 Tahun 2012 tentang Sistem Peradilan Pidana Anak (UU No. 11 Tahun 2012)

Pasal 58 ayat (3) butir b UU No. 11 Tahun 2012 pada pokoknya mengatur bahwa dalam hal anak korban dan/atau anak saksi tidak dapat hadir untuk memberikan keterangan di depan sidang pengadilan, maka hakim dapat memerintahkan agar dilakukan pemeriksaan langsung jarak jauh dengan alat komunikasi audiovisual. ${ }^{32}$ Dalam proses pemeriksaan tersebut, anak korban dan/atau anak saksi nantinya didampingi oleh orang tua/wali, pembimbing kemasyarakatan atau pendamping lainnya. ${ }^{33}$

3. Undang-Undang Republik Indonesia Nomor 9 Tahun 2013 tentang Pencegahan dan Pemberantasan Tindak Pidana Pendanaan Terorisme (UU No. 9 Tahun 2013)

Pasal 39 UU UU No. 9 Tahun 2013 pada pokoknya mengatur bahwa pemeriksaan saksi dan/atau ahli di sidang pengadilan terhadap tindak pidana pendanaan terorisme dapat dilakukan dengan media audiovisual yang disesuaikan dengan kebutuhan dan kondisi yang dihadapi. ${ }^{34}$ Agar pemeriksaan tersebut sah, maka ada beberapa syarat yang harus dipenuhi, yaitu: a. tidak di bawah paksaan atau tekanan; b. tidak dipandu; dan c. didampingi oleh penuntut umum dan jika diperlukan, maka didampingi juga oleh advokat. ${ }^{35}$ Adapun, apabila pemberian keterangan oleh saksi dan/atau ahli tersebut dilakukan di luar wilayah Negara Kesatuan Republik Indonesia, maka wajib didampingi oleh pejabat Kantor Perwakilan Republik Indonesia. ${ }^{36}$ Selain itu,

31 Undang-Undang R.I., No. 31 Tahun 2014, Perubahan atas Undang-Undang Republik Indonesia Nomor 13 Tahun 2006 tentang Perlindungan Saksi dan Korban, L.N.R.I. Tahun 2014 No. 293, Pasal 1 butir 6.

32 Undang-Undang R.I., No. 11 Tahun 2012, Sistem Peradilan Pidana Anak, L.N.R.I. Tahun 2012 No. 153, Pasal 58 ayat (3) butir b.

33 Id

34 Undang-Undang R.I., No. 9 Tahun 2013, Pencegahan dan Pemberantasan Tindak Pidana Pendanaan Terorisme, L.N.R.I. Tahun 2013 No. 5406, Pasal 39.

35 Id., Pasal 40 ayat (2) butir a sampai dengan c.

36 Id., Pasal 40 ayat (3). 
media audiovisual yang digunakan di ruang sidang pengadilan harus menghadap hakim dengan suara yang dapat didengar secara terbuka. ${ }^{37}$

4. Undang-Undang Republik Indonesia Nomor 5 Tahun 2018 tentang Perubahan Atas Undang-Undang Republik Indonesia Nomor 15 Tahun 2003 Tentang Penetapan Peraturan Pemerintah Pengganti Undang-Undang Nomor 1 Tahun 2002 Tentang Pemberantasan Tindak Pidana Terorisme Menjadi UndangUndang (UU No. 5 Tahun 2018)

Salah satu bentuk perlindungan terhadap pelapor, ahli, dan saksi beserta keluarganya dalam tindak pidana terorisme adalah melalui pemberian keterangan tanpa hadirnya saksi yang dilakukan secara jarak jauh melalui alat komunikasi audio visual. Hal tersebut ditegaskan dalam Pasal 34A ayat (1) butir d UU No. 5 Tahun.

5. Undang-Undang Republik Indonesia Nomor 21 Tahun 2007 tentang Pemberantasan Tindak Pidana Perdagangan Orang (UU No. 21 Tahun 2007)

Pasal 34 UU No. 21 Tahun 2007 pada pokoknya mengatur bahwa dalam hal saksi dan/atau korban tidak dapat dihadirkan di sidang pengadilan, maka keterangan saksi dan/atau korban tersebut dapat diberikan secara jarak jauh melalui alat komunikasi audiovisual. ${ }^{38}$ Selain itu, terhadap saksi dan/atau korban anak, atas persetujuan hakim, pemeriksaannya dapat dilakukan di luar sidang pengadilan dengan perekaman. ${ }^{39}$ Adapun, yang dimaksud dengan perekaman di sini adalah dilakukan dengan alat rekam audio dan/atau audiovisual. ${ }^{40}$ Proses pemeriksaan saksi dan/atau korban anak dengan perekaman tersebut dilakukan di hadapan pejabat yang berwenang, yaitu penyidik atau penuntut umum. ${ }^{41}$

6. Perjanjian Kerja Sama MA, Kejagung, dan Kemenkumham tentang Pelaksanaan Persidangan Melalui Teleconference

\footnotetext{
Id., Pasal 40 ayat (4).

Undang-Undang R.I., No. 21 Tahun 2007, Pemberantasan Tindak Pidana Perdagangan Orang, L.N.R.I. Tahun 2007 No. 4720, Pasal 34.

39 Id., Pasal 40 ayat (1).

40 Id., Penjelasan Pasal 40 ayat (1).

41 Id., Pasal 40 ayat (2) jo. Penjelasan Pasal 40 ayat (2).
} 
Perjanjian tersebut dibuat guna dijadikan sebagai pedoman dalam melaksanakan persidangan melalui teleconference. ${ }^{42}$ Dalam perjanjian tersebut juga diatur mengenai pembagian wewenang dan tanggung jawab para pihak, seperti menyediakan sarana dan prasarana penunjang yang memadai guna kepentingan persidangan melalui teleconference di tempat masing-masing. ${ }^{43}$ Selain itu, Kemenkumham juga berwenang dan bertanggung jawab untuk mempersiapkan tahanan dan/atau warga binaan pemasyarakatan yang berstatus sebagai terdakwa/saksi dalam persidangan yang dilaksanakan dengan memanfaatkan media teleconference pada Rutan/ Lapas setempat. ${ }^{44}$

7. Rancangan Kitab Undang-Undang Hukum Acara Pidana Draft 2012 (Rancangan KUHAP Draft 2012)

Berdasarkan Pasal 180 ayat (2) RancanganKUHAP Draft 2021, keterangan saksi dapat diberikan secara jarak jauh melalui alat komunikasi audiovisual dengan dihadiri oleh penasihat hukum dan penuntut umum apabila saksi tidak dapat dihadirkan dalam pemeriksaan di sidang pengadilan. ${ }^{45}$ Lebih lanjut lagi mengenai tata cara dan syarat pemberian kesaksian secara jarak jauh nantinya akan diatur dengan peraturan pemerintah. 46

Selain ketentuan-ketentuan di atas, bahwa terdapat ketentuan yang memberikan kemungkinan secara implisit dapat dilaksanakannya persidangan pidana melalui sarana audiovisual. Ketentuan tersebut yaitu Pasal 4 butir c Peraturan Pemerintah Republik Indonesia Nomor 2 Tahun 2002 tentang Tata Cara Perlindungan terhadap Korban dan Saksi dalam Pelanggaran Hak Asasi Manusia yang Berat (PP No. 2 Tahun 2002) yang pada pokoknya mengatur bahwa salah satu bentuk perlindungan terhadap korban atau saksi dalam pelanggaran berat HAM yaitu dengan pemberian keterangan di sidang pengadilan tanpa bertatap

42 Perjanjian Kerja Sama antara Mahkamah Agung Republik Indonesia, Kejaksaan Republik Indonesia, dan Kementerian Hukum dan Hak Asasi Manusia Republik Indonesia, No. 402/DJU/HM.01.1/4/2020, No. KEP-17/E/Ejp/04/2020, No. PAS-08.HH.05.05 Tahun 2020, Pelaksanaan Persidangan Melalui Teleconference, Pasal 1 ayat (1).

43 Id., Pasal 3 ayat (1) butir b jo. Pasal 3 ayat (2) butir b jo. Pasal 3 ayat (3) butir c.

44 Id., Pasal 3 ayat (3) butir b.

45 Rancangan Undang-Undang R.I. Draft 2012, Hukum Acara Pidana, Pasal 180 ayat (2).

46 Rancangan Undang-Undang R.I. Draft 2012, Hukum Acara Pidana, Pasal 180 ayat (10). 
muka dengan terdakwa. ${ }^{47}$ Ketentuan tersebut diterapkan oleh majelis hakim pada perkara pelanggaran berat HAM atas nama terdakwa Hulman Gultom sebagai dasar bagi pemeriksaan saksi tanpa kehadiran di persidangan secara langsung sehingga dimungkinkan dilaksanakannya persidangan secara teleconference. ${ }^{48}$

\section{Legalitas Pemeriksaan Terdakwa di Persidangan Melalui Media}

\section{Teleconference di Indonesia Selama Masa Pandemi COVID-19}

Pola perkembangan pandemi COVID-19 yang terus bergerak secara eksponensial dengan laju pertumbuhan grafik yang terus positif atau naik, menyebabkan interaksi antar manusia harus mengalami perubahan secara drastis. Demi menekan laju angka pertumbuhan penyebaran COVID-19 tersebut, pemerintah telah menetapkan kebijakan physical distancing (pembatasan fisik) yang berimplikasi pada penyesuaian sistem kerja terhadap beberapa instansi, termasuk institusi badan peradilan. Salah satu penyesuaian sistem kerja tersebut yaitu dengan melaksanakan persidangan secara online dengan menggunakan teleconference sebagai solusi penyelesaian perkara pidana di pengadilan. Sebagai payung hukum dari kebijakan ini, sudah ada beberapa produk hukum dari lembaga peradilan terkait penyelesaian perkara pidana melalui media teleconference.

Pada tanggal 23 Maret 2020, Ketua MA telah menerbitkan SEMA No. 1 Tahun 2020. Dalam surat edaran tersebut, persidangan perkara pidana tetap dilaksanakan khusus untuk perkara pidana yang terdakwanya sedang ditahan dan penahanannya tidak dapat diperpanjang lagi selama masa pencegahan penyebaran COVID-19.49 Kemudian, pada tanggal 24 Maret 2020, Menteri Hukum dan Hak Asasi Manusia Republik Indonesia (Menkumham) juga menerbitkan Surat

7 Peraturan Pemerintah R.I., No. 2 Tahun 2002, Tata Cara Perlindungan terhadap Korban dan Saksi dalam Pelanggaran Hak Asasi Manusia yang Berat, L.N.R.I. Tahun 2002 No. 6, Pasal 4 butir c.

48 Penetapan Majelis Hakim Pengadilan Hak Asasi Manusia Ad Hoc pada Pengadilan Negeri Jakarta Pusat nomor 08/Pid.HAM Ad Hoc 2002.PN Jakarta Pusat, tertanggal 3 Desember 2002.

49 Surat Edaran Mahkamah Agung R.I., No. 1 Tahun 2020, Pedoman Pelaksanaan Tugas Selama Masa Pencegahan Penyebaran Coronavirus Disease 2019 (COVID-19) di Lingkungan Mahkamah Agung dan Badan Peradilan yang Berada di Bawahnya, butir 2 huruf a. 
Menteri Hukum dan Hak Asasi Manusia Republik Indonesia Nomor M.HH.PK.01.01.01-03 perihal Pencegahan dan Pengendalian Penyebaran Coronavirus Disease 2019 (COVID-19) di Lapas/Rutan (Surat Menkumham Tahun 2020 perihal Pencegahan dan Pengendalian Penyebaran COVID-19 di Lapas/Rutan). Dalam surat ini ditegaskan bahwa untuk penahanan yang perpanjangannya tidak lagi dimungkinkan, maka sidangnya dapat dilakukan di Lapas atau Rutan yang terbuka untuk publik melalui media internet (live streaming) atau melaksanakan sidang melalui teleconference.

Tiga hari kemudian, pada tanggal 27 Maret 2020, Jaksa Agung Republik Indonesia (Jaksa Agung) mengeluarkan Surat Jaksa Agung Republik Indonesia Nomor B-049/A/SUJA/03/2020 Tahun 2020 tentang Optimalisasi Pelaksanaan Tugas, Fungsi, dan Kewenangan di Tengah Upaya Mencegah Penyebaran COVID 19 (Surat Jaksa Agung Tahun 2020 tentang Optimalisasi Pelaksanaan Tugas, Fungsi, dan Kewenangan di Tengah Upaya Mencegah Penyebaran COVID-19). Salah satu poin dalam surat ini adalah mengupayakan sidang perkara pidana melalui sarana video conference/live streaming yang dalam pelaksanaannya dikoordinasi bersama ketua pengadilan negeri dan kepala Rutan/Lapas. ${ }^{50}$ Sejalan dengan surat Jaksa Agung di atas, pada tanggal yang sama, 27 Maret 2020, Direktur Jenderal Badan Peradilan Umum Mahkamah Agung Republik Indonesia (Dirjen Badilum) juga mengeluarkan Surat Dirjen Badilum Tahun 2020 perihal Persidangan Perkara Pidana Secara Teleconference.

Dalam perkembangannya, Ketua MA, Jaksa Agung, dan Menkumham sepakat untuk mengambil suatu langkah kerja sama antar-institusi yang terkait dengan proses peradilan. Langkah kerja sama ini dituangkan melalui Perjanjian Kerja Sama MA, Kejagung, dan Kemenkumham tentang Pelaksanaan Persidangan Melalui Teleconference yang ditandatangani pada tanggal 13 April 2020. Dalam perjanjian kerjasama ini, dijelaskan bahwa persidangan pidana dilakukan di kantor masing-masing lembaga, baik di pengadilan negeri, kantor kejaksaan,

50 Surat Jaksa Agung R.I., No. B-049/A/SUJA/03/2020 Tahun 2020, Optimalisasi Pelaksanaan Tugas, Fungsi, dan Kewenangan di Tengah Upaya Mencegah Penyebaran COVID-19, butir 2. 
maupun di Rutan/Lapas dengan menggunakan media teleconference. ${ }^{51}$ Namun demikian, dalam perjanjian kerja sama tersebut tidak diatur mengenai mekanisme pelaksanaan persidangan pidana secara teleconference. Akibatnya, dalam praktik terdapat beberapa model mekanisme persidangan pidana dengan media teleconference yang terjadi di masa pandemi COVID-19, yaitu:

1. Majelis hakim, penuntut umum, dan penasihat hukum berada di ruang sidang pengadilan negeri, sedangkan terdakwa berada di Rutan/Lapas. Contoh pengadilan negeri yang menerapkan mekanisme seperti ini adalah Pengadilan Negeri Bukittinggi ${ }^{52}$ dan Pengadilan Negeri Bandung53.

2. Majelis hakim berada di ruang sidang pengadilan negeri, penuntut umum berada di kantor kejaksaan, terdakwa bersama penasihat hukumnya berada di Rutan/Lapas. Mekanisme tersebut telah diterapkan oleh Pengadilan Negeri Jepara $^{54}$ dan Pengadilan Negeri Cilacap 55.

3. Majelis hakim dan penasihat hukum berada di ruang sidang pengadilan negeri, penuntut umum berada di kantor kejaksaan, terdakwa berada di Rutan/Lapas. Mekanisme ini telah diterapkan oleh Pengadilan Negeri Kota Cirebon. ${ }^{56}$

4. Majelis hakim berada di ruang sidang pengadilan negeri, penuntut umum dan penasihat hukum berada di kantor kejaksaan, terdakwa berada di

51 Perjanjian Kerja Sama antara Mahkamah Agung Republik Indonesia, Kejaksaan Republik Indonesia, dan Kementerian Hukum dan Hak Asasi Manusia Republik Indonesia, No. 402/DJU/HM.01.1/4/2020, No. KEP-17/E/Ejp/04/2020, No. PAS-08.HH.05.05 Tahun 2020, Pelaksanaan Persidangan Melalui Teleconference, Pasal 3 butir 2 huruf $b$ jo. butir 2 huruf $b$ jo. butir 3 huruf c.

52 Hasil wawancara dengan Bapak Reza Rahim selaku Kepala Seksi Tindak Pidana Khusus Kejaksaan Negeri Bukittinggi, 5 Agustus 2020.

53 Hasil wawancara dengan Praktisi Hukum yaitu Advokat di Bandung, 27 Agustus 2020.

54 Dinas Kominfo Jateng, "Kejaksaan Negeri Jepara Lakukan Sidang Pidana Daring", https://jatengprov.go.id/beritadaerah/kejaksaan-negeri-jepara-lakukan-sidang-pidanadaring/, diakses 28 Agustus 2020.

55 TIM TI PN Cilacap Kelas IA, "Cegah Corona Meluas, Pengadilan Negeri Cilacap Terapkan Persidangan Pidana melalui Teleconference", http://pn-cilacap.go.id/index.php/tentangpengadilan/kegiatan-pengadilan/924-cegah-corona-meluas-pengadilan-negeri-cilacapterapkan-persidangan-pidana-melalui-teleconference, diakses 28 Agustus 2020.

56 Radar Cirebon, "Sidang Pidana Teleconference", https://www.radarcirebon.com/2020/04/09/sidang-pidana-teleconference/, diakses 21 Juli 2020. 
Rutan/Lapas. Mekanisme seperti ini diterapkan oleh Pengadilan Negeri Kuala Kurun. ${ }^{57}$

5. Majelis hakim berada di ruang sidang pengadilan negeri, penuntut umum di kantor kejaksaan, penasihat hukum di kantor masing-masing, dan terdakwa di Rutan/Lapas. Contoh pengadilan negeri yang menerapkan mekanisme seperti ini adalah Pengadilan Negeri Liwa. ${ }^{58}$

Mekanisme persidangan pidana dengan media teleconference memang menjadi ranah yurisdiksi masing-masing pengadilan. Meskipun belum terlihat suatu integrasi dan kesamaan prosedur antarpengadilan, namun dari seluruh mekanisme persidangan di atas terdapat suatu kesamaan yaitu terdakwa tetap berada di Rutan/Lapas ketika persidangan berlangsung. Meskipun demikian, perlu diingat bahwa dalam hukum acara pidana dikenal suatu prinsip yaitu hadirnya terdakwa di persidangan. Hadirnya terdakwa di persidangan merupakan prinsip yang fundamental dalam hukum acara pidana Indonesia. Dalam hal ini, Pasal 154 ayat (1) KUHAP telah mengatur bagaimana tata cara menghadirkan terdakwa di depan sidang pengadilan yang berbunyi: "hakim ketua sidang memerintahkan supaya terdakwa dipanggil masuk dan jika ia dalam tahanan, ia dihadapkan dalam keadaan bebas". ${ }^{99}$ Jika diperhatikan dengan saksama, rasio dari pasal ini adalah terdakwa hadir secara fisik dan langsung di ruang sidang pengadilan dalam keadaan bebas, baik jasmani maupun rohaninya.

Lebih lanjut lagi, Penjelasan Pasal 154 ayat (4) KUHAP juga secara tegas mengatur bahwa: "kehadiran terdakwa di persidangan merupakan kewajiban dari terdakwa, bukan merupakan haknya, jadi terdakwa harus hadir di sidang pengadilan". ${ }^{60}$ Ketentuan ini dengan tegas menjelaskan bahwa hadirnya terdakwa

57 Pengadilan Negeri Kuala Karun, “Sidang Teleconference Digelar Di PN Kuala Kurun Guna Cegah Penyebaran Virus Corona (Covid-19)”, http://pn-kualakurun.go.id/berita-sidangteleconference-digelar-di-pn-kuala-kurun-guna-cegah-penyebaran-virus-corona-covid19.html, diakses 28 Agustus 2020.

58 Pengadilan Negeri Liwa, "Darurat Corona, PN Liwa Mengadakan Sidang Secara Teleconference", https://pn-liwa.go.id/berita-terkini/berita-terkini/darurat-corona-pn-liwa-mengadakansidang-secara-teleconference-2, diakses 28 Agustus 2020.

59 Undang-Undang R.I., No. 8 Tahun 1981, Hukum Acara Pidana, L.N.R.I. Tahun 1981 No. 76, Pasal 154 ayat (1).

60 Id., Penjelasan Pasal 154 ayat (4). 
secara langsung di pengadilan merupakan suatu keharusan yang mutlak agar persidangan pidana dapat dilangsungkan. Jika terdakwa tidak hadir, maka persidangan harus ditunda dan tidak dapat dilakukan sampai penuntut umum mampu menghadirkan kembali terdakwa tersebut di depan sidang pengadilan. ${ }^{61}$ Apabila penuntut umum telah mengupayakan untuk menghadirkan terdakwa dengan sungguh-sungguh namun terdakwa tetap tidak dapat dihadirkan dengan baik, maka si terdakwa tersebut dapat dihadirkan secara paksa. ${ }^{62}$

Ratio legis dari kehadiran terdakwa di persidangan adalah sebagai upaya penghormatan terhadap HAM terdakwa dengan maksud agar terdakwa dapat melakukan pembelaan atas perkara yang didakwakan kepadanya. ${ }^{63} \mathrm{Hal}$ ini dilakukan karena dalam proses persidangan pidana terdakwa berhadapan dengan negara yang memiliki kekuasaan, dalam hal ini diwakili oleh penuntut umum. Untuk mencegah terjadinya abuse of power, maka negara perlu melimitasi kewenangan yang dimiliki oleh aparatur penegak hukum melalui hukum acara pidana. Oleh karena itu, KUHAP perlu menjamin dan memastikan terpenuhinya hak-hak terdakwa selama proses persidangan berlangsung, seperti mendapatkan penasihat hukum, diadili dalam sidang yang terbuka untuk umum, mengajukan saksi yang menguntungkan, mempersiapkan pembelaan, sampai dengan mengajukan upaya hukum.

Berdasarkan hal-hal di atas, praktik persidangan pidana dengan terdakwa berada di Rutan/Lapas menimbulkan polemik baru di masyarakat karena dianggap bertentangan dengan asas kehadiran terdakwa di persidangan. Sebagai contoh, yakni ketika Penasihat Hukum beserta terdakwa I Gede Ary Astina alias Jerinx menyatakan menolak persidangan dengan media teleconference dan meminta agar majelis hakim dapat melaksanakan persidangan secara langsung (tatap muka) di Pengadilan Negeri Denpasar. ${ }^{64}$

\footnotetext{
61 Id., Pasal 154 ayat (4).

62 Id., Penjelasan Pasal 154 ayat (6).

63 Suriady Harianja, Peradilan In Absentia pada Perkara Tindak Pidana Korupsi dalam Perspektif HAM Terdakwa, 2 Unnes Law Journal, 36, 36, April 2013.

64 Kompas, "Jerinx "Walk Out" Saat Sidang Perdana, Keberatan Digelar via Telekonferensi", https://regional.kompas.com/read/2020/09/10/12211961/jerinx-walk-out-saat-sidangperdana-keberatan-digelar-via-telekonferensi?page=all, diakses 2 Desember 2020.
} 
Berbicara mengenai persidangan pidana secara teleconference di masa pandemi COVID-19, seperti yang dijelaskan sebelumnya bahwa mekanisme persidangan ini mengharuskan terdakwa tetap berada di Rutan/Lapas selama proses persidangan berlangsung. Dengan demikian, praktik persidangan tersebut sudah jelas menyimpangi asas kehadiran terdakwa sebagaimana telah diatur dalam KUHAP.65 Hal ini dikarenakan KUHAP sebagai sumber hukum utama persidangan pidana di Indonesia mengharuskan terdakwa hadir secara fisik dalam keadaan bebas di depan sidang pengadilan. Oleh karena persidangan pidana melalui media teleconference di masa pandemi COVID-19 tidak sesuai dengan asas kehadiran terdakwa sebagaimana telah diatur dalam KUHAP, maka secara mutatis mutandis juga bertentangan dengan asas legalitas.

Berkaitan dengan pelaksanaan persidangan secara teleconference di masa pandemi COVID-19 dan hubungannya dengan asas legalitas, maka muncul pertanyaan: bagaimana persidangan secara teleconference di masa pandemi COVID-19 juga menyalahi asas legalitas yang terdapat dalam hukum acara pidana? Menjawab pertanyaan ini, maka perlu dilihat terlebih dahulu kedudukan alas hukum persidangan pidana secara teleconference di masa pandemi COVID-19. Payung hukum pelaksanaan persidangan tersebut adalah Surat Menkumham Tahun 2020 perihal Pencegahan dan Pengendalian Penyebaran COVID-19 di Lapas/Rutan, Surat Jaksa Agung Tahun 2020 tentang Optimalisasi Pelaksanaan Tugas, Fungsi, dan Kewenangan di Tengah Upaya Mencegah Penyebaran COVID19, Surat Dirjen Badilum Tahun 2020 perihal Persidangan Perkara Pidana Secara Teleconference, dan Perjanjian Kerja Sama MA, Kejagung, dan Kemenkumham tentang Pelaksanaan Persidangan Melalui Teleconference.

Dalam hukum administrasi negara, surat edaran yang dikeluarkan oleh Menkumham, Jaksa Agung, dan Dirjen Badilum termasuk dalam kategori beleidsregels (aturan kebijakan). Menurut S.F. Marbun dan Moh. Mahfud MD, ada empat bentuk kemungkinan dari norma hukum, yaitu pengaturan, penetapan,

65 Hasil wawancara dengan Bapak Boby Heryanto selaku Kepala Seksi Pengelolaan Barang Bukti dan Barang Rampasan Kejaksaan Negeri Bukittinggi, 5 Agustus 2020. 
putusan hakim, dan aturan kebijakan. ${ }^{66}$ Jimly Asshiddiqie menyatakan bahwa beleidsregels atau policy rules tidak dapat dikategorikan sebagai peraturan meski isinya juga bersifat mengatur karena pada dasarnya beleidsregels mengatur halhal yang sangat teknis sehingga tidak dituangkan dalam bentuk peraturan perundang-undangan yang resmi, contohnya petunjuk pelaksana, petunjuk teknis, surat edaran, instruksi, rencana kerja, dan sebagainya. ${ }^{67}$ Seperti halnya Jimly Asshiddiqie, Philipus Hadjon dan Bagir Manan juga sependapat bahwa beleidsregels bukanlah termasuk dalam peraturan perundang-undangan. ${ }^{68}$

Masih berkaitan dengan pengaturan persidangan pidana secara teleconference di masa pandemi COVID-19 oleh ketiga surat di atas, Pasal 28 Undang-Undang Republik Indonesia Nomor 48 Tahun 2009 tentang Kekuasaan Kehakiman salah satu isinya mengatur bahwa hukum acara MA serta badan peradilan yang berada di bawahnya diatur dengan undang-undang. ${ }^{69}$ Sejalan dengan ketentuan di atas, G.J.M. Corstens sebagaimana dikutip oleh Komariah Emong Sapardjaja menyatakan bahwa hukum acara pidana mempunyai ruang lingkup nasional yang tidak dapat diundangkan dalam peraturan perundangundangan di bawah derajat undang-undang melainkan hanya dapat diubah dengan undang-undang pula. $^{70}$ Ratio legis-nya adalah untuk mencegah penyalahgunaan kekuasaan oleh aparat penegak hukum yang dalam hal ini dapat mengurangi bahkan meniadakan hak-hak dasar warga negara. ${ }^{71}$ Dengan begitu, persidangan secara teleconference di masa pandemi COVID-19 yang diatur melalui ketiga surat sebagaimana telah Penulis ungkapkan sebelumnya merupakan suatu langkah yang keliru.

66 S.F. Marbun dan Moh. Mahfud MD, Pokok-Pokok Hukum Administrasi Negara, Cetakan Kelima, Liberty, Yogyakarta, 2009, hlm. 94.

67 Jimly Asshiddiqie, Konstitusi Ekonomi, Cetakan Pertama, Buku Kompas, Jakarta, 2010, hlm.19.

68 Icha Satriani, 2015, Kedudukan Surat Edaran Mahkamah Agung, Skripsi, Program Studi Ilmu Hukum Fakultas Hukum Universitas Hasanuddin, Makassar, hlm. 34.

69 Undang-Undang R.I., No. 48 Tahun 2009, Kekuasaan Kehakiman, L.N.R.I. Tahun 2009 No. 157, Pasal 28.

70 Komariah Emong Sapardjaja, Kajian dan Catatan Hukum atas Putusan Praperadilan Nomor 04/Pid.Prad/2015/PN.Jkt.Sel tertanggal 16 Februari 2015 pada Kasus Budi Gunawan, Sebuah Analisis Kritis, 2 Padjadjaran Jurnal Ilmu Hukum, 14 , 17, 2015.

71 Tristam P. Moeliono dan Widati Wulandari, Asas Legalitas dalam Hukum Acara Pidana: Kritikan terhadap Putusan MK tentang Praperadilan, 22 Jurnal Hukum Ius Quia Iustum, 594, 599, Oktober 2015. 
Kemudian terkait dengan payung hukum berupa Perjanjian Kerja Sama MA, Kejagung, dan Kemenkumham tentang Pelaksanaan Persidangan Melalui Teleconference, bahwa pada prinsipnya alas hukum tersebut merupakan salah satu macam perjanjian yang termasuk dalam ranah hukum perdata. Menurut Sudikno Mertokusumo, perjanjian adalah hubungan hukum antara dua orang yang bersepakat untuk menimbulkan akibat hukum. ${ }^{72}$ Berdasarkan pengertian tersebut, maka dapat dipahami bahwa perjanjian akan menimbulkan perikatan kepada para pihak. Mengenai pihak-pihak yang terikat dalam perjanjian, Pasal 1338 Kitab Undang-Undang Hukum Perdata pada pokoknya mengatur bahwa semua perjanjian yang dibuat secara sah, berlaku sebagai undang-undang bagi mereka yang membuatnya. ${ }^{73}$ Ketentuan tersebut secara tegas mengatur bahwa perjanjian yang sah hanya mengikat bagi para pihak yang membuatnya atau yang sering dikenal dengan asas pacta sunt servanda. Dalam hal ini, Perjanjian Kerja Sama MA, Kejagung, dan Kemenkumham tentang Pelaksanaan Persidangan Melalui Teleconference di bagian akhirnya menegaskan bahwa perjanjian ini dibuat untuk dipatuhi dan dilaksanakan oleh para pihak. In casu a quo, para pihak yang dimaksud dalam perjanjian tersebut adalah MA, Kejagung, dan Kemenkumham. Dengan demikian, pihak-pihak yang terlibat dalam persidangan pidana secara teleconference selain MA, Kejagung, dan Kemenkumham seperti penasihat hukum seharusnya tidak terikat pada perjanjian kerja sama tersebut. ${ }^{74}$

Selain itu, perjanjian kerja sama sebagaimana telah Penulis uraikan sebelumnya mengatur mengenai pelaksanaan persidangan pidana melalui teleconference yang mana secara mutatis mutandis juga mengatur hukum acara dari pelaksanaan persidangan tersebut. Perlu diketahui, bahwa hukum acara pidana merupakan hukum publik karena mengatur hubungan antara individu dengan negara. ${ }^{75}$ Sedangkan, perjanjian kerja sama ini termasuk ke dalam dimensi

72 Sudikno Mertokusumo, Mengenal Hukum, Suatu Pengantar, Cetakan Keempat, Liberty, Yogyakarta, 2007, hlm. 118.

73 Pasal 1338 Kitab Undang-Undang Hukum Perdata.

74 Hasil wawancara dengan Praktisi Hukum yaitu Advokat di Bandung, 27 Agustus 2020.

75 Eddy O.S. Hiariej, Prinsip-Prinsip Hukum Pidana, Edisi Revisi, Cahaya Atma Pustaka, Yogyakarta, 2016, hlm. 16. 
hukum privat dan hanya mengikat kepada para pihak yang membuat perjanjian ${ }^{76}$ sehingga menurut hemat Penulis perjanjian kerja sama bukanlah produk hukum yang tepat dalam mengatur hukum beracara terhadap perkara pidana. Dengan demikian, Perjanjian Kerja Sama MA, Kejagung, dan Kemenkumham tentang Pelaksanaan Persidangan Melalui Teleconference tidak bisa dijadikan sebagai dasar pelaksanaan persidangan melalui teleconference di tengah masa pandemi COVID-19.

Berdasarkan uraian di atas, pada dasarnya Penulis sepakat dengan adanya sidang pidana dengan menggunakan media teleconference selama masa pandemi COVID-19 karena mengingat adanya asas Salus Populi Suprema Lex Esto (keselamatan rakyat merupakan hukum tertinggi) ${ }^{77}$. Selain itu, dengan tetap melaksanakan sidang pidana di masa pandemi COVID-19 merupakan bentuk penghormatan terhadap HAM terdakwa untuk segera diproses perkaranya. ${ }^{78}$ Namun demikian, kebijakan ini tentunya juga harus didasarkan dengan payung hukum yang tepat. Dalam hal ini, Penulis berpendapat bahwa mengeluarkan Peraturan Pemerintah Pengganti Undang-Undang (Perppu) sementara atau mengesahkan Rancangan KUHAP ${ }^{79}$ dapat menjadi solusi yang lebih tepat sehingga mampu mengenyampingkan ketentuan beracara terhadap perkara pidana sebagaimana yang diatur dalam KUHAP. Sebab, Perppu maupun Rancangan KUHAP merupakan alas hukum yang setara dengan undang-undang.

\section{Penutup}

Berdasarkan pembahasan di atas, maka dapat ditarik kesimpulan sebagai berikut. Pertama, pengaturan pemeriksaan sidang perkara pidana melalui media teleconference di Indonesia sejatinya telah diatur dalam berbagai peraturan perundang-undangan. Adapun, pengaturan tersebut terdapat dalam UU No. 13 Tahun 2006, UU No. 11 Tahun 2012, UU No. 9 Tahun 2013, UU No. 5 Tahun 2018,

76 Hasil wawancara dengan Praktisi Hukum yaitu Advokat di Bandung, 27 Agustus 2020.

77 Hasil wawancara dengan Bapak Reza Rahim selaku Kepala Seksi Tindak Pidana Khusus Kejaksaan Negeri Bukittinggi, 5 Agustus 2020.

78 Hasil wawancara dengan Praktisi Hukum yaitu Advokat di Bandung, 27 Agustus 2020.

79 Hasil wawancara dengan Bapak Boby Heryanto selaku Kepala Seksi Pengelolaan Barang Bukti dan Barang Rampasan Kejaksaan Negeri Bukittinggi, 5 Agustus 2020. 
UU No. 21 Tahun 2007, Perjanjian Kerja Sama MA, Kejagung, dan Kemenkumham tentang Pelaksanaan Persidangan Melalui Teleconference, dan Rancangan KUHAP Draft 2012. Selain itu, pengaturan pelaksanaan pemeriksaan sidang perkara pidana melalui media teleconference di Indonesia diatur secara implisit dalam PP No. 2 Tahun 2002.

Kedua, pemeriksaan sidang perkara pidana melalui media teleconference selama masa pandemi COVID-19 yang mengharuskan terdakwa tetap berada di Rutan/Lapas selama proses persidangan berlangsung bertentangan dengan asas kehadiran terdakwa di persidangan sebagaimana diatur oleh KUHAP. Selain itu, payung hukum pelaksanaan persidangan tersebut berupa Surat Menkumham Tahun 2020 perihal Pencegahan dan Pengendalian Penyebaran COVID-19 di Lapas/Rutan, Surat Jaksa Agung Tahun 2020 tentang Optimalisasi Pelaksanaan Tugas, Fungsi, dan Kewenangan di Tengah Upaya Mencegah Penyebaran COVID19, dan Surat Dirjen Badilum Tahun 2020 perihal Persidangan Perkara Pidana Secara Teleconference bukan merupakan peraturan perundang-undangan yang setingkat dengan undang-undang sehingga tidak dapat mengenyampingkan KUHAP. Kemudian terkait payung hukum berupa Perjanjian Kerja Sama MA, Kejagung, dan Kemenkumham tentang Pelaksanaan Persidangan Melalui Teleconference, Penulis berpendapat perjanjian tersebut bukan dasar hukum yang tepat mengingat sifatnya yang privat sehingga tidak dapat mengatur ketentuan hukum beracara. Di samping itu, oleh karena bentuknya perjanjian, maka hanya mengikat kepada para pihak yang menyepakati perjanjian. In casu a quo, penasihat hukum tidak terikat dengan perjanjian tersebut.

Berdasarkan kesimpulan di atas, Penulis juga menyampaikan saran, yaitu: Pertama, pemerintah seharusnya menerbitkan Perppu guna memberikan legitimasi yang dapat mengenyampingkan KUHAP terhadap pemeriksaan sidang perkara pidana melalui media teleconference selama masa pandemi COVID-19. Kedua, DPR diharapkan untuk segera membahas kembali dan mengesahkan Rancangan KUHAP sehingga dapat memberikan payung hukum yang kuat mengenai pemeriksaan sidang perkara pidana melalui media teleconference baik pada masa pandemi COVID-19 maupun di masa yang akan datang. 


\section{Daftar Pustaka}

\section{Buku:}

Eddy O.S. Hiariej, Prinsip-Prinsip Hukum Pidana, Edisi Revisi, Cahaya Atma Pustaka, Yogyakarta, 2016.

Fathul Wahid, Kamus Istilah Teknologi Informasi, Andi Offset, Yogyakarta, 2002..

Jimly Asshiddiqie, Konstitusi Ekonomi, Cetakan Pertama, Buku Kompas, Jakarta, 2010.

Lilik Mulyadi, Bunga Rampai Hukum Pidana, Perspektif, Teoretis, dan Praktik, Cetakan Kedua, Alumni, Bandung, 2012.

S.F. Marbun dan Moh. Mahfud MD, Pokok-Pokok Hukum Administrasi Negara, Cetakan Kelima, Liberty, Yogyakarta, 2009.

Sudikno Mertokusumo, Mengenal Hukum, Suatu Pengantar, Cetakan Keempat, Liberty, Yogyakarta, 2007.

\section{Jurnal:}

Harapan Harapan, et.al., Coronavirus Disease 2019 (COVID-19): A Literature Review, 13 Journal of Infection and Public Health, May 2020.

Komariah Emong Sapardjaja, Kajian dan Catatan Hukum atas Putusan Praperadilan Nomor 04/Pid.Prad/2015/PN.Jkt.Sel tertanggal 16 Februari 2015 pada Kasus Budi Gunawan, Sebuah Analisis Kritis, 2 Padjadjaran Jurnal Ilmu Hukum, 2015.

Muhammad Adnan Shereen, et.al., COVID-19 Infection: Origin, Transmission, and Characteristics of Human Coronaviruses, 24 Journal of Advanced Research, July 2020.

Ruth Marina Damayanti Siregar, Legalitas Keterangan Saksi Melalui Teleconference sebagai Alat Bukti dalam Perkara Pidana, 5 Jurisprudence, Maret 2015.

Suriady Harianja, Peradilan In Absentia pada Perkara Tindak Pidana Korupsi dalam Perspektif HAM Terdakwa, 2 Unnes Law Journal, April 2013.

Tristam P. Moeliono dan Widati Wulandari, Asas Legalitas dalam Hukum Acara Pidana: Kritikan terhadap Putusan MK tentang Praperadilan, 22 Jurnal Hukum Ius Quia Iustum, Oktober 2015.

\section{Hasil Penelitian/Tugas Akhir:}

Dien Kalpika Kasih, 2014, Keterangan Saksi Video Conference pada Kasus Cebongan Yogyakarta (Tinjauan Yuridis Putusan No. 48-K/PM II11/AD/VI/2013), Skripsi, Program Studi Ilmu Hukum Fakultas Hukum Universitas Jenderal Soedirman, Purwokerto.

Icha Satriani, 2015, Kedudukan Surat Edaran Mahkamah Agung, Skripsi, Program Studi Ilmu Hukum Fakultas Hukum Universitas Hasanuddin, Makassar.

Lalu Mariyun, 2004, Penyelenggaraan Sidang Pengadilan dengan Metode Teleconference Ditinjau dari Aspek Hukum Pembuktian (Studi Kasus Perkara Pidana No. 354/PID/B/2002/PN.JAK-SEL.), Tesis, Program Pascasarjana Fakultas Hukum Universitas Gadjah Mada, Yogyakarta. 
Lulu Azmi Sharfina, 2018, Keabsahan Kesaksian (Keterangan Saksi) yang Disampaikan Secara Teleconference di Persidangan, Skripsi, Program Studi Ilmu Hukum Fakultas Hukum Universitas Islam Indonesia, Yogyakarta.

Sekar Dianing Pertiwi Soetanto, 2008, Perkembangan Alat Bukti dalam Pembuktian Tindak Pidana pada KUHAP dan Undang-Undang Khusus di Indonesia, Skripsi, Program Studi Ilmu Hukum Fakultas Hukum Universitas Sebelas Maret, Surakarta.

Sintha Dewi, 2012, Kajian Yuridis Terhadap Keterangan Saksi Melalui Audio Visual (Teleconference) di Persidangan Perkara Pidana, Tesis, Program Pascasarjana Hukum dan Sistem Peradilan Pidana Fakultas Hukum Universitas Indonesia, Jakarta.

\section{Internet:}

Dinas Kominfo Jateng, Kejaksaan Negeri Jepara Lakukan Sidang Pidana Daring, https://jatengprov.go.id/beritadaerah/kejaksaan-negeri-jepara-lakukansidang-pidana-daring/.

Kompas, Breaking News: Jokowi Umumkan Dua Orang di Indonesia Positif Corona, https://nasional.kompas.com/read/2020/03/02/11265921/breakingnews-jokowi-umumkan-dua-orang-di-indonesia-positif-corona?page=all.

Kompas, Jerinx "Walk Out" Saat Sidang Perdana, Keberatan Digelar via Telekonferensi, https://regional.kompas.com/read/2020/09/10/12211961/jerinx-walk out-saat-sidang-perdana-keberatan-digelar-via-telekonferensi?page=all.

Pengadilan Negeri Kuala Karun, Sidang Teleconference Digelar Di PN Kuala Kurun Guna Cegah Penyebaran Virus Corona (Covid-19), http://pnkualakurun.go.id/berita-sidang-teleconference-digelar-di-pn-kuala-kurunguna-cegah-penyebaran-virus-corona-covid19.html.

Pengadilan Negeri Liwa, Darurat Corona, PN Liwa Mengadakan Sidang Secara Teleconference, https://pn-liwa.go.id/berita-terkini/beritaterkini/darurat-corona-pn-liwa-mengadakan-sidang-secarateleconference- 2 .

Radar Cirebon, Sidang Pidana Teleconference, https://www.radarcirebon.com/2020/04/09/sidang-pidanateleconference/.

TIM TI PN Cilacap Kelas IA, Cegah Corona Meluas, Pengadilan Negeri Cilacap Terapkan Persidangan Pidana melalui Teleconference, http://pncilacap.go.id/index.php/tentang-pengadilan/kegiatan-pengadilan/924cegah-corona-meluas-pengadilan-negeri-cilacap-terapkan-persidanganpidana-melalui-teleconference.

World Health Organization, The Classical Definition of A Pandemic is Not Elusive, https://www.who.int/bulletin/volumes/89/7/11088815/en/\#: :text=A\%20pandemic\%20is\%20defined\%20as,are\%20not $\% 20$ considered\%20pandemics.

World Health Organization, "WHO Coronavirus Disease (COVID-19) Dashboard", https://covid19.who.int/. 
World Health Organization, WHO Director-General's Opening Remarks at The Media Briefing on COVID-19-11 March 2020", https://www.who.int/dg/speeches/detail/who-director-general-sopening-remarks-at-the-media-briefing-on-covid-19---11-march-2020.

\section{Peraturan Perundang-undangan:}

Kitab Undang-Undang Hukum Perdata.

Undang-Undang Nomor 5 Tahun 2018 tentang Perubahan Atas Undang-Undang Republik Indonesia Nomor 15 Tahun 2003 tentang Penetapan Peraturan

Pemerintah Pengganti Undang-Undang Nomor 1 Tahun 2002 tentang Pemberantasan Tindak Pidana Terorisme Menjadi Undang-Undang.

Undang-Undang Nomor 8 Tahun 1981 tentang Hukum Acara Pidana.

Undang-Undang Nomor 9 Tahun 2013 tentang Pencegahan dan Pemberantasan Tindak Pidana Pendanaan Terorisme.

Undang-Undang Nomor 11 Tahun 2012 tentang Sistem Peradilan Pidana Anak.

Undang-Undang Nomor 12 Tahun 2011 tentang Pembentukan Peraturan

Perundang-Undangan.

Undang-Undang Nomor 13 Tahun 2006 tentang Perlindungan Saksi dan Korban.

Undang-Undang Nomor 21 Tahun 2007 tentang Pemberantasan Tindak Pidana Perdagangan Orang.

Undang-Undang Nomor 31 Tahun 2014 tentang Perubahan atas Undang-Undang Republik Indonesia Nomor 13 Tahun 2006 tentang Perlindungan Saksi dan Korban.

Undang-Undang Nomor 48 Tahun 2009 tentang Kekuasaan Kehakiman.

Peraturan Pemerintah Nomor 2 Tahun 2002 tentang Tata Cara Perlindungan terhadap Korban dan Saksi dalam Pelanggaran Hak Asasi Manusia yang Berat.

Surat Edaran Mahkamah Agung Republik Indonesia Nomor 1 tahun 2020 tentang Pedoman Pelaksanaan Tugas Selama Masa Pencegahan Penyebaran Coronavirus Disease 2019 (COVID-19) di Lingkungan Mahkamah Agung dan Badan Peradilan yang Berada di Bawahnya.

Surat Jaksa Agung Republik Indonesia Nomor B-049/A/SUJA/03/2020 Tahun 2020 perihal Optimalisasi Pelaksanaan Tugas, Fungsi, dan Kewenangan di Tengah Upaya Mencegah Penyebaran COVID-19.

Surat Direktur Jenderal Badan Peradilan Umum Mahkamah Agung Republik Indonesia Nomor 379/DJU/PS.00/3/2020 perihal Persidangan Perkara Pidana Secara Teleconference.

Perjanjian Kerja Sama antara Mahkamah Agung Republik Indonesia, Kejaksaan Republik Indonesia, dan Kementerian Hukum dan Hak Asasi Manusia Republik Indonesia Nomor 402/DJU/HM.01.1/4/2020, Nomor KEP- 
17/E/Ejp/04/2020, Nomor PAS-08.HH.05.05 Tahun 2020 tentang

Pelaksanaan Persidangan Melalui Teleconference.

Rancangan Kitab Undang-Undang Hukum Acara Pidana Draft 2012.

\section{Putusan Pengadilan:}

Penetapan Majelis Hakim Pengadilan Hak Asasi Manusia Ad Hoc pada Pengadilan

Negeri Jakarta Pusat nomor 08/Pid.HAM Ad Hoc 2002.PN Jakarta Pusat, tertanggal 3 Desember 2002.

\section{Wawancara:}

Wawancara dengan Bapak Boby Heryanto selaku Kepala Seksi Pengelolaan Barang Bukti dan Barang Rampasan Kejaksaan Negeri Bukittinggi, 5 Agustus 2020. Wawancara dengan Bapak Reza Rahim selaku Kepala Seksi Tindak Pidana Khusus Kejaksaan Negeri Bukittinggi, 5 Agustus 2020.

Wawancara dengan Praktisi Hukum yaitu Advokat di Bandung, 27 Agustus 2020. 